\title{
Removing Hexavalent Chromium from Subsurface Waters with Anion-Exchange Resin
}

\section{June 1995}

Richard A. Torres* 
This report has been reproduced directly from the best available copy.

Available to DOE and DOE contractors from the Office of Scientific and Technical Information

P.O. Box 62, Oak Ridge, TN 37831

Prices available from (615) 576-8401, FTS 626-8401

Available to the public from the

National Technical Information Service

U.S. Department of Commerce

5285 Port Royal Rd.

Springfield, VA 22161

Work performed under the auspices of the U.S. Department of Energy by Lawrence Livermore National Laboratory under Contract W-7405-ENG-48. 


\section{DISCLAIMER}

Portions of this document may be illegible in electronic image products. Images are produced from the best available original document. 


\title{
Removing Hexavalent Chromium from Subsurface Waters with Anion-Exchange Resin
}

\author{
June 1995
}

\author{
Richard A. Torres*
}

DISCLAIMER

This report was prepared as an account of work sponsored by an agency of the United States Government. Neither the United States Government nor any agency thereof, nor any of their employees, makes any warranty, express or implied, or assumes any legal liability or responsibility for the accuracy, completeness, or usefulness of any information, apparatus, product, or process disclosed, or represents that its use would not infringe privately owned rights. Reference herein to any specific commercial product, process, or service by trade name, trademark, manufacturer, or otherwise does not necessarily constitute or imply its endorsement, recommendation, or favoring by the United States Government or any agency thereof. The views and opinions of authors expressed herein do not necessarily state or reflect those of the United States Government or any agency thereof. 


\section{Contents}

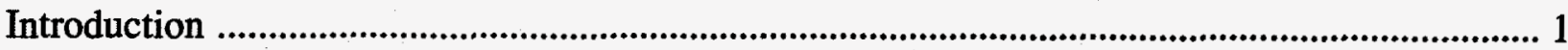

Experimental Methods ........................................................................................................... 1

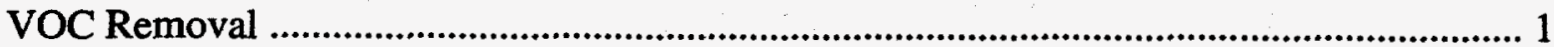

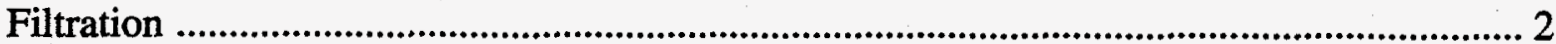

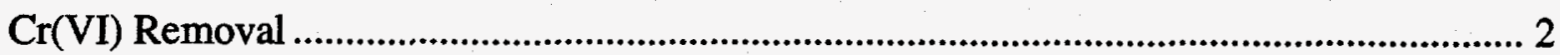

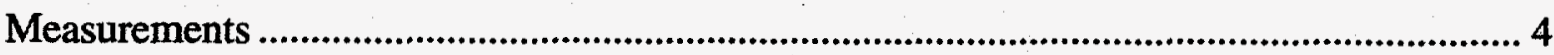

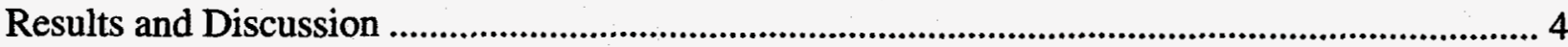

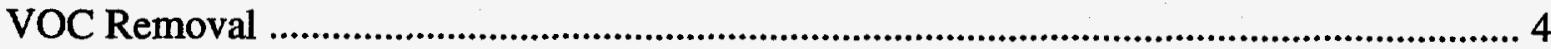

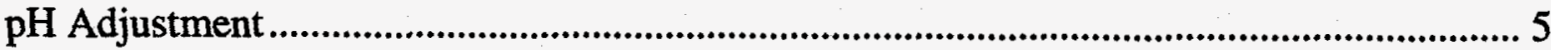

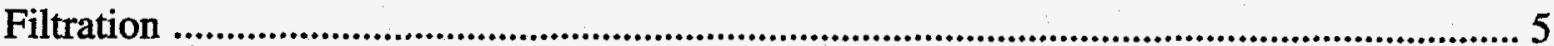

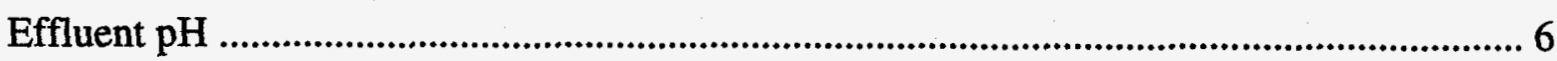

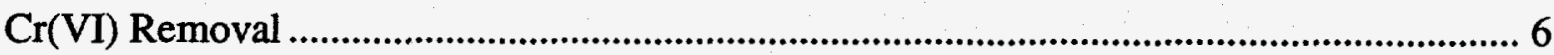

Resin Regeneration ......................................................................................................... 10

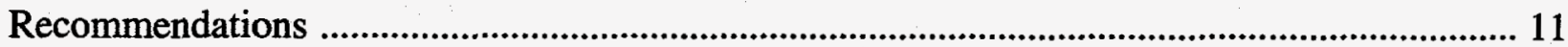

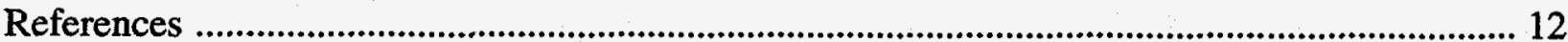

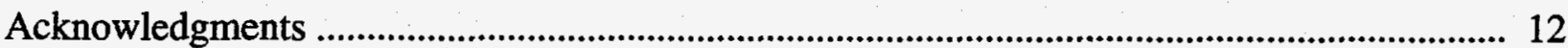

Appendix A. Data From Experiments with A600 Resin ........................................................... A-1

\section{Tables}

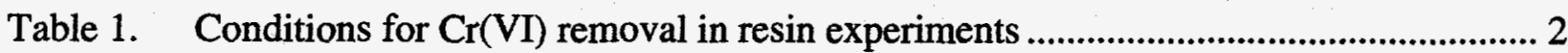

Table 2. VOC stripping efficiency as a function of air/water ratio .......................................... 4

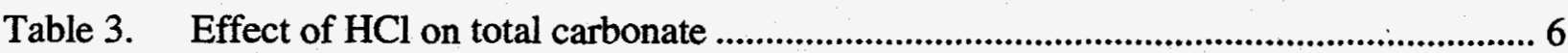

Table 4. Total bed volumes of water treated before breakthrough of nitrate, sulfate,

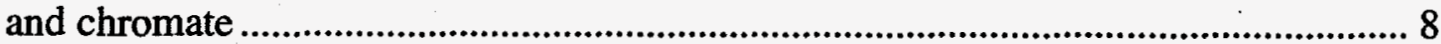

Table 5. Total bed volumes of water treated before chromium breakthrough ............................ 9

Table 6. Cr recovery from the columns used in $\mathrm{Cr}-4$ and $\mathrm{Cr}-5$ in each regeneration step ...... 10

Table 7. Regeneration of the column used in $\mathrm{Cr}-6$ with $1.5 \mathrm{M} \mathrm{NaCl}$................................. 11

Table 8. Anion concentrations in LLNL wells ................................................................... 11

\section{Figures}

Figure 1. Components of the anion-resin chromatography system 



\section{Removing Hexavalent Chromium from Subsurface Wells with Anion-Exchange Resin}

\section{Introduction}

Some subsurface waters at Lawrence Livermore National Laboratory (LLNL) are contaminated with volatile organic compounds (VOCs). Hexavalent chromium, $\mathrm{Cr}(\mathrm{VI})$, is also present in the ground water; however, the source of the $\mathrm{Cr}(\mathrm{VI})$ may be natural. The $\mathrm{Cr}(\mathrm{VI})$ still must be treated if brought to the surface because its concentration exceeds discharge standards. We are planning facilities for removing the VOCs and $\mathrm{Cr}(\mathrm{VI})$ to a level below the discharge standards. The planned treatment includes the following steps:

- Pumping the water to the surface facility.

- Purging the VOCs with air and absorbing them on activated carbon. The VOCs in LLNL's subsurface waters are primarily chlorinated organic solvents, such as dichloroethylene (DCE), trichloroethylene (TCE), perchloroethylene (PCE), and chloroform $\left(\mathrm{CHCl}_{3}\right)$. Contamination levels range from tens to thousands of parts per billion.

- Filtering the water.

- Passing the water through anion-exchange resin to remove the Cr. The $\mathrm{Cr}$ in LLNL subsurface waters occurs almost entirely as $\mathrm{Cr}(\mathrm{VI})$, which exists as the chromate anion, $\mathrm{CrO}_{4}{ }^{2-}$, at environmental $\mathrm{pH}$. $\mathrm{Cr}$ levels range from tens to hundreds of parts per billion.

- Discharging the treated water into the local arroyos. The relevant discharge criteria are $5 \mathrm{ppb}$ total VOCs, $11 \mathrm{ppb} \mathrm{Cr}(\mathrm{VI})$, and $\mathrm{pH}$ between 6.5 and 8.5, inclusive.

This report describes laboratory experiments undertaken to learn how the proposed treatment facility can be expected to operate. The laboratory results are expected to supply vendors with the detailed performance specifications needed to prepare bids on the Cr removal portion of the treatment facility. The treatment facility is expected to process 60 gallons per minute (gpm) of water by stripping VOCs with 720 standard cubic feet per minute (scfm) of air and removing $\mathrm{Cr}$ (VI) with $60 \mathrm{ft}^{3}$ of resin.

\section{Experimental Methods}

We used water from well MW-4 in our experiments. The water was collected in 5-gal plastic carboys, which were precleaned by rinsing with dilute nitric acid, deionized water, and, finally, with the wellwater itself, before being filled. Samples of water from wells P-701, MW-351, and MW-361 were analyzed for comparison. These smaller samples were collected in glass bottles after rinsing the bottles with the wellwater.

\section{VOC Removal}

VOCs were purged by bubbling air through the water until a 90/1 air/water volume ratio was reached. (This $90 / 1$ volume ratio is used in currently operating treatment facilities at LLNL for 
removing VOCs.) Typically, $2 \mathrm{~L} / \mathrm{min}$ of air were bubbled through $20 \mathrm{~L}$ of water for 16 hours. The air was presaturated with water vapor (by bubbling it through laboratory water) to avoid evaporating significant amounts of water. The air was introduced at the bottom of the sample container through a fritted-glass impinger, which produces a stream of fine bubbles. The height of water above the impinger was $25 \mathrm{~cm}$ or greater.

\section{Filtration}

Table 1 outlines the conditions for each resin experiment. Complete data are contained in Appendix A.

Water for $\mathrm{Cr}-1,-2,-3$, and -7 was filtered through glass frits. A coarse frit was used for $\mathrm{Cr}-1$ and -2 , while medium frits were used for $\mathrm{Cr}-3$ and -7 . In addition, for $\mathrm{Cr}-1,-2$, and -3 , the gravity-feed reservoir contained a polymer frit with a nominal pore size of 20 to $35 \mu \mathrm{m}$. The presence of this additional frit was overlooked during the course of $\mathrm{Cr}-1$ analysis, although it caused no difficulty. For $\mathrm{Cr}-2$, the flow rate gradually decreased, and finally stopped altogether as the reservoir-frit became plugged with solids. $\mathrm{Cr}-2$ tests showed that the flow was blocked in the reservoir and not the column. After $\mathrm{Cr}-3$ tests, the gravity-feed reservoir was replaced with a plastic syringe barrel, eliminating the extra frit. For $\mathrm{Cr}-4,-5$, and -6 , the water was filtered through Whatman 541 filter paper, which has a nominal pore size of 20 to $25 \mu \mathrm{m}$.

\section{Cr(VI) Removal}

Puralite A600 anion-exchange resin was used for all experiments. This resin is a strongly basic tetraalkylammonium resin with a styrene-divinylbenzene copolymer gel matrix. It has a nominal capacity of $1.5 \mathrm{eq} / \mathrm{L}$ of resin bed. After measuring the desired $3.5 \mathrm{~mL}$ of resin bed in a $5-\mathrm{mL}$ graduated cylinder, the resin was transferred to a Bio-Rad Econo-column $(0.7 \mathrm{~cm} \mathrm{ID} \times \sim 9 \mathrm{~cm})$. The resin was used in the chloride form, except for $\mathrm{Cr}-3$ and $\mathrm{Cr}-7$, which used resin in the hydroxide and sulfate forms, respectively.

Experimental flow rates were $1.2 \mathrm{~mL} / \mathrm{min}\left(2.6 \mathrm{gpm} / \mathrm{ft}^{3}\right)$ except for $\mathrm{Cr}-6$, which had a flow rate of $2.3 \mathrm{~mL} / \mathrm{min}\left(4.9 \mathrm{gpm} / \mathrm{ft}^{3}\right)$. We used higher flow rates than the $1 \mathrm{gpm} / \mathrm{ft}^{3}$ planned for the actual treatment facility to shorten the experiments as much as possible. However, the flow rates are still within the supplier's recommended operating conditions of 1 to $5 \mathrm{gpm} / \mathrm{ft}^{3}$ of resin bed.

To further decrease experimental time, most of the experiments involved water in which the $\mathrm{Cr}(\mathrm{VI})$ concentration was elevated above natural levels by the addition of potassium dichromate. In

Table 1. Conditions for $\mathrm{Cr}$ (VI) removal in resin experiments.

\begin{tabular}{c|c|c|c}
\hline \hline & Cr (ppb) & pH adjustment & Resin form \\
\hline Cr-1 & 3,100 & Yes & Chloride \\
Cr-2 & 3,010 & No & Chloride \\
Cr-3 & 32 & No & Hydroxide \\
Cr-4 & 35,600 & No & Chloride \\
Cr-5 & 35,600 & No & Chloride \\
Cr-6 & 35 & No & Chloride \\
Cr-7 & 3,010 & No & Sulfate \\
\hline \hline
\end{tabular}


these cases, the $\mathrm{Cr}(\mathrm{VI})$ spike solution was adjusted to $\mathrm{pH} 8$ before adding it to the wellwater. Addition of the $\mathrm{Cr}$ spike caused only $\sim 1 \%$ dilution of the native wellwater. The VOCs were stripped after the addition of the $\mathrm{Cr}$ spike.

Figure 1 shows components of the anion-resin chromatography system, which included (A) a container of wellwater, (B) a 25 -mL autoburet, (C) a 10-mL gravity-reservoir, (D) the $3.5-\mathrm{mL}$ anionresin column, and (E) a fraction collector. The autoburet, which automatically filled when it was empty, dispensed wellwater at the chosen flow rate from a carboy into the gravity reservoir. The height of the reservoir was adjusted until the rate at which it emptied equaled the rate at which the autoburet filled the reservoir. The column effluent was directed to a fraction collector to allow for automatic, timed sample collection.

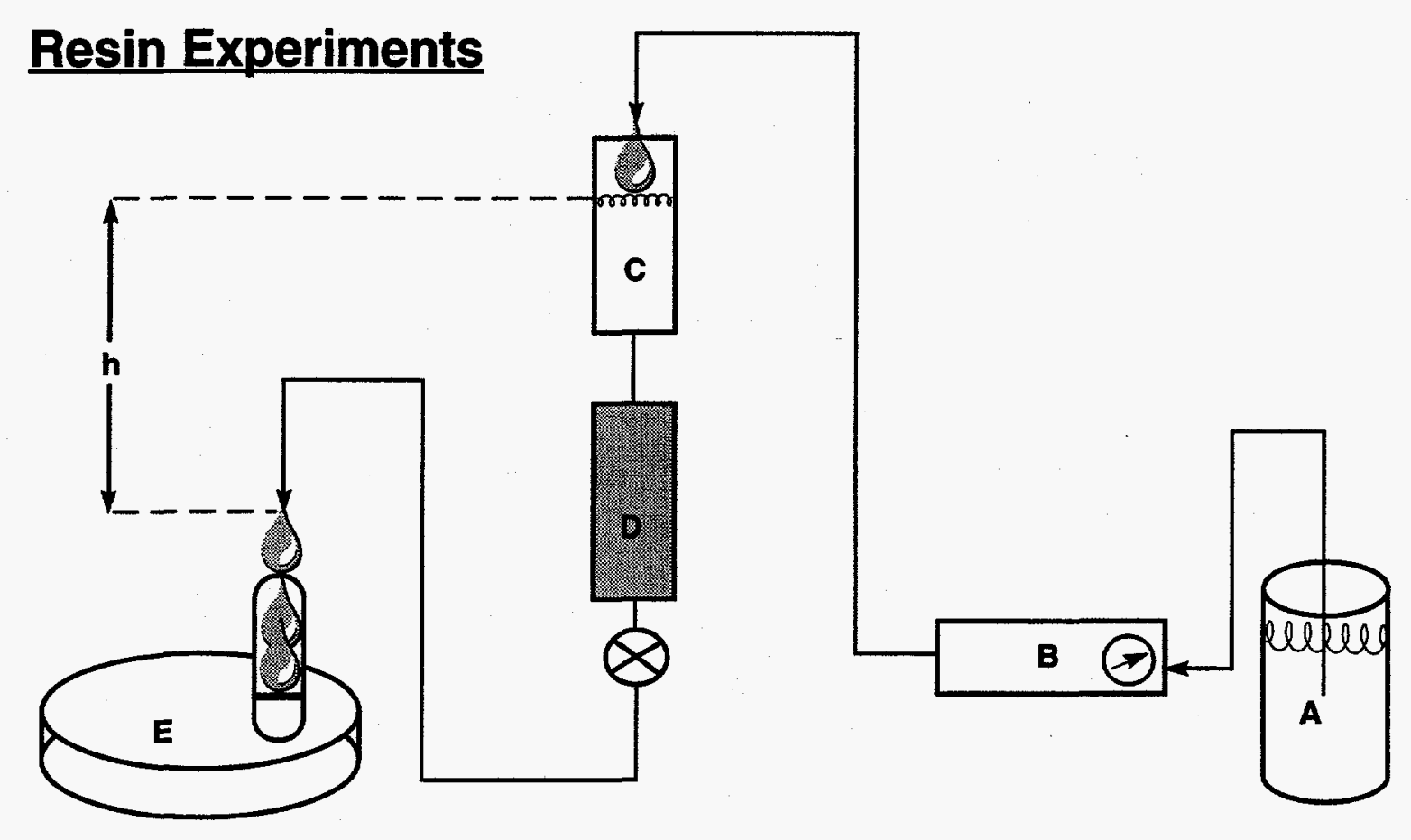

$$
\begin{aligned}
& A=\text { Water carboy } \\
& B=\text { Autoburet } \\
& C=\text { Gravity reservoir } \\
& D=\text { Anion-resin } \\
& E=\text { Fraction collector }
\end{aligned}
$$

Figure 1. Components of the anion-resin chromatography system: (A) container of wellwater, (B) autoburet, (C) gravity reservoir, (D) resin column, and (E) fraction collector. The difference in heights $(\mathrm{h})$ between the liquid level in $\mathrm{C}$ and the effluent point at $\mathrm{E}$ determines the flow rate through the column. 


\section{Measurements}

The following analytical measurements (and techniques) were used for samples generated during the experiments.

- Total $\mathrm{Cr}$, calcium $(\mathrm{Ca})$, magnesium $(\mathrm{Mg})$, and silica $(\mathrm{Si})$ at parts per million (ppm) levels by Inductively Coupled Plasma Emission Spectroscopy (ICP-ES).

- Total $\mathrm{Cr}$ at ppb levels by Graphite Furnace Atomic Absorption Spectroscopy (GF-AA).

- $\mathrm{Cr}(\mathrm{VI})$ by colorimetry with diphenylcarbazide reagent (EPA Method 7196) using a colorimeter with a 5-cm path-length fiber-optic dipping probe.

- Total chloride $(\mathrm{Cl}-)$, nitrate $\left(\mathrm{NO}_{3}{ }^{-}\right)$, and sulfate $\left(\mathrm{SO}_{4}{ }^{2-}\right)$ at ppm levels by ion chromatography (IC).

- Total carbonate $\left(\mathrm{CO}_{3}{ }^{2-}\right)$ and bicarbonate $\left(\mathrm{HCO}_{3}^{-}\right)$at ppm levels by potentiometric titration.

- Total inorganic/organic carbon at ppm levels by Total Carbon Analyzer.

- $\mathrm{pH}$ was measured with glass/calomel reference electrodes calibrated operationally with commercially available $\mathrm{pH} 4$ and $\mathrm{pH} 7$ buffers.

- VOCs by purge-and-trap gas chromatography-mass spectroscopy (GC-MS).

\section{Results and Discussion}

MW-4 wellwater has the following characteristics from samples measured during this work: $\mathrm{pH}$ 7.8 to $8.0,35 \mathrm{ppb} \mathrm{Cr}, 62 \mathrm{ppm} \mathrm{Ca}, 22 \mathrm{ppm} \mathrm{Mg}, 15 \mathrm{ppm} \mathrm{Si}, 360 \mathrm{ppm}$ bicarbonate, $110 \mathrm{ppm}$ chloride, $22 \mathrm{ppm}$ nitrate, $45 \mathrm{ppm}$ sulfate, and $\sim 30 \mathrm{ppb}$ total VOCs ( $85 \%$ TCE.) The $\mathrm{pH}$ and total carbonate concentrations can vary slightly with the age of the sample, and in particular with whether it has been allowed to outgas; the $\mathrm{pH}$ increases and the total carbonate decreases slightly on standing. The VOC levels are also slightly lower than in samples measured directly at the well.

\section{VOC Removal}

One experiment was performed to measure the effect of the stripping duration on both the $\mathrm{pH}$ and the stripping efficiency. Results are summarized in Table 2.

Obviously, the $90 / 1$ air/water volume ratio is not necessary for VOC removal. A ratio between 10 and 15 is probably sufficient.

Table 2. VOC stripping efficiency as a function of air/water ratio.

\begin{tabular}{c|c|c}
\hline \hline Stripping ratio & pH & $\begin{array}{c}\text { VOC } \\
\text { (ppb) }\end{array}$ \\
\hline 0 & 7.83 & 30 \\
8 & 8.52 & 1 \\
20 & 8.81 & ND \\
50 & 8.98 & ND \\
90 & 9.00 & ND \\
\hline \hline
\end{tabular}


These data also show that the laboratory stripping process raises the $\mathrm{pH}$ of the water significantly above the discharge limit. The increase to $\mathrm{pH} 9$ was seen consistently in all of the experiments (except for the one in which extra acid was added.) The existing LLNL treatment facilities that strip with an identical air/water ratio reportedly do not exceed $\mathrm{pH}$ 8.5. The stripping efficiency in the laboratory is probably greater than the field operation because of smaller bubbles (and larger surface area) in the laboratory.

\section{pH Adjustment}

Carbonate concentrations in wellwater were measured by $\mathrm{pH}$ titration with $\mathrm{HCl}$ titrant. When both carbonate and bicarbonate occur together in solution, the titration curve shows two equivalence points. The first, at $\mathrm{pH} \mathrm{8.5,} \mathrm{occurs} \mathrm{when} \mathrm{all} \mathrm{of} \mathrm{the} \mathrm{carbonate} \mathrm{has} \mathrm{been} \mathrm{titrated} \mathrm{to} \mathrm{bicarbonate;} \mathrm{the}$ second, at $\mathrm{pH} 4.6$, occurs when the bicarbonate (from the partially titrated carbonate and the initial untitrated bicarbonate) has been titrated to dissolved carbon dioxide. Titrations of native MW-4 water, which has an initial $\mathrm{pH}$ of $<8.5$, therefore, have a single equivalence point, corresponding to $360 \mathrm{ppm}$ of bicarbonate. After the laboratory stripping process, the water has a $\mathrm{pH}$ of 9.2. Therefore, in stripped water, a small fraction of the total carbonate occurs as carbonate, while the bulk occurs as bicarbonate. From the two equivalence points found in the titrations with $\mathrm{HCl}$, the stripped MW-4 water has $32 \mathrm{ppm}$ of carbonate and $290 \mathrm{ppm}$ of bicarbonate. This is $10 \%$ less total carbonate than that found in the native water. Therefore, native MW-4 water when exposed to ambient temperature and pressure is slightly supersaturated with respect to carbonate. If the increase to $\mathrm{pH} 9$ were to occur in the treatment facility, then a plant operating at $60 \mathrm{gpm}$ would require only $0.03 \mathrm{gpm}$ of $1 \mathrm{M} \mathrm{HCl}$ to titrate the $32 \mathrm{ppm}$ of carbonate to $\mathrm{pH} 8.5$.

\section{Filtration}

The high carbonate and $\mathrm{Ca} / \mathrm{Mg}$ concentrations, coupled with the fact that $\mathrm{pH}$ increases as the water is stripped, makes the precipitation of $\mathrm{Ca}(\mathrm{Mg}) \mathrm{CO}_{3}$ likely. Analytical data (from Appendix A) show that $\mathrm{Mg}$ concentrations in the column effluents are constant in all of the experiments (except for $\mathrm{Cr}-3$, which will be discussed later). However, $\mathrm{Cr}-2,-5$, and -6 show that the $\mathrm{Ca}$ concentration decreases as the experiments proceed. This is consistent with the roughly 10-fold decrease in solubility of $\mathrm{CaCO}_{3}$ compared to $\mathrm{MgCO}_{3}$. Therefore, the column of resin acts as a finer filter than the 20- to 35- $\mu \mathrm{m}$ filters used in the experiments.

The accumulation of solids in the resin column can be minimized by:

- Filtering the water to tighter tolerances. The water in $\mathrm{Cr}-7$ was filtered through a medium glass frit. After filtration, it had the smallest Ca concentration, which remained constant throughout the experiment. More work is required to quantitatively determine the maximum pore size such that influent and effluent $\mathrm{Ca}$ concentrations are constant.

- Acidifying the water before the stripping process to eliminate the bulk of the carbonate. The water in $\mathrm{Cr}-1$ was acidified with $\mathrm{HCl}$ to remove $90 \%$ of the carbonate. Filtering the acidified water did not change the $\mathrm{Ca}$ concentration, which remained constant throughout the experiment.

Separate experiments (Table 3 ) show that adding $\mathrm{HCl}$ to the native wellwater before stripping removes carbonate on an equimolar basis. 
Table 3. Effect of $\mathrm{HCl}$ on total carbonate. Observed ratio $=[\mathrm{TIC}] /[\mathrm{TIC}]_{0}$ as measured on TIC analyzer. Calculated ratio $=1-\left([\mathrm{HCl}] /[\mathrm{TIC}]_{0}\right)$.

\begin{tabular}{c|c}
\hline Observed ratio & Calculated ratio \\
\hline 0.003 & -0.014 \\
0.050 & 0.053 \\
0.087 & 0.101 \\
0.145 & 0.154 \\
0.184 & 0.200 \\
1.000 & 0.984 \\
\hline \hline
\end{tabular}

Although the accumulation of precipitate in the chloride-form resin does not appear to decrease the performance of new resin, we have no data on the continued reuse of the resin. As a minimum requirement, there should be a means of vigorously backwashing the column with water to help dislodge any precipitate.

\section{Effluent pH}

In all experiments, the initial effluents from the columns had a lower $\mathrm{pH}$ than the influent solutions. The $\mathrm{pH}$ decreases because the resin initially removes a large fraction of the total carbonate present in the water. As the bicarbonate is displaced from the resin by the more tightly bound chloride, nitrate, and sulfate anions, the $\mathrm{pH}$ increases, gradually approaching the influent $\mathrm{pH}$. From $\mathrm{Cr}-6$, the test of the chloride-form resin with native MW-4 water, the effluent reaches $\mathrm{pH} 6.5$ after $\sim 20$ bed volumes of water have been treated. For the proposed treatment facility, this is equivalent to $1,200 \mathrm{ft}^{3}$ $(9,000 \mathrm{gal})$ of water from the first 2.5 hours of operation. There are several options for handling this water. It can be:

- Recycled through the resin until the $\mathrm{pH}$ reaches $\mathrm{pH}$ 6.5.

- Diluted with fresh effluent in a holding/mixing tank until the $\mathrm{pH}$ reaches $\mathrm{pH} 6.5$.

- Adjusted to $\mathrm{pH}>6.5$ with sodium bicarbonate or sodium hydroxide solution in a holding/ mixing tank. The use of sodium bicarbonate solution, which naturally has $\mathrm{pH} 8.3$, would prevent overshooting $\mathrm{pH}$ 8.5. However, a solution of sodium hydroxide with the same molar concentration as the sodium bicarbonate solution requires only half the volume.

\section{Cr(VI) Removal}

In general, an ion-exchange reaction can be written as:

$$
R X+Y=R Y+X,
$$

where $R$ denotes the resin phase. This reaction has an equilibrium constant:

$$
K_{e q}=\frac{[R Y][X]}{[Y][R X]},
$$


where $[R Y] /[Y]$ and $[R X] /[X]$ are the distribution coefficients for the anions between the resin and solution phases. Therefore,

$$
[R Y]=K_{e q} \frac{[R X][Y]}{[X]}:
$$

For a two-component system, the amount of anion $Y$ held by the resin is directly proportional to the equilibrium concentration of $Y$, and inversely proportional to the equilibrium concentration of the competing anion $X$. When the resin concentrations are expressed in units of moles per gram, the distribution coefficients are denoted by $K_{d}$. When the resin concentrations are expressed in units of moles per volume, the distribution coefficients are denoted by $D_{V} \cdot D_{V}^{Y}$ is a measure of when the anion $Y$ will "break through" into the effluent from a resin column. The value of $D_{V} Y$ is equivalent to the number of bed volumes of solution that pass through the column before the concentration of anion $Y$ in the effluent reaches one-half of the influent concentration. When $D_{V} Y$ is large:

$$
D_{V}^{Y}=\frac{K_{e q} R_{t}}{[X]+K_{e q}[Y]}
$$

where $R_{t}$ is the total number of equivalents per milliliter of bed volume. Eq. (4) predicts that for sufficiently small concentrations of $Y$ (when the product $K_{e q}[Y]$ is small compared to the concentration $[X]), D_{V} Y$ is independent of [Y]. It also predicts how $D_{V} Y_{\text {varies when the product } K_{e q}}$ $[Y]$ is not negligible.

The wellwater, however, is not a two-component system. The bicarbonate, chloride, nitrate, and sulfate anions all compete with chromate for exchange sites on the resin. An increase in the concentration of any of these anions can be expected to decrease the $\mathrm{Cr}$ distribution coefficient, and the amount of water that can be treated before $\mathrm{Cr}$ breakthrough occurs.

Furthermore, the anions have varying selectivities for the resin. The preference of the resin for the anions is expected to be:

$$
\mathrm{OH}^{-}(0.09)<\mathrm{HCO}_{3}-(0.32)<\mathrm{Cl}^{-}(1.0)<\mathrm{NO}_{3}-(3.8)<<\mathrm{SO}_{4}{ }^{2-}\left(>10^{2}\right)<\mathrm{CrO}_{4}{ }^{2-}\left(>10^{3}\right) \text {. }
$$

The numbers in parentheses are the equilibrium constants for Eq. (2) relative to chloride as the competing anion (Marhol, 1982). They indicate the relative preference, affinity, or selectivity of the resin toward different anions. (The sulfate and chromate numbers are guesses.) This ordering is inversely correlated with increasing hydrated radii for ions of like charge, and directly correlated with increasing total charge. The ordering is confirmed in our resin experiments.

Anion analyses of the fractions collected during the resin experiments show that bicarbonate is eluted first, followed successively by chloride, nitrate, sulfate, and chromate. (Macroscopic amounts of free hydroxide can not exist in solutions that contain bicarbonate.) Because of this ordering, an increase in nitrate concentration would decrease the $\mathrm{Cr}$ distribution ratio more than a comparable increase in chloride concentration, and an increase in sulfate concentration would have the largest effect.

As mentioned previously, acidifying the water before the stripping process prevents the accumulation of solids (presumably $\mathrm{CaCO}_{3}$ ) in the resin column. Experiments with $\mathrm{Cr}-1$ and $\mathrm{Cr}-2$ 
differed only in that the water for $\mathrm{Cr}-1$ was acidified with $\mathrm{HCl}$ to remove $\sim 90 \%$ of the total carbonate. Table 4 shows the breakthrough volumes for nitrate, sulfate, and chromate found from these two experiments. The breakthrough volumes are those required to reach $11 \mathrm{ppm}$ and $22 \mathrm{ppm}(50 \%$ of the influent concentrations) for nitrate and sulfate, respectively, and $11 \mathrm{ppb}$ for $\mathrm{Cr}$.

Table 4. Total bed volumes of water treated before breakthrough of nitrate, sulfate, and chromate.

\begin{tabular}{c|c|c|c}
\hline \hline & Nitrate & Sulfate & Chromate \\
\hline Cr-1 & 359 & 590 & 955 \\
$C_{r}-2$ & 457 & 728 & 1,380 \\
Cr-2/Cr-1 & 1.3 & 1.2 & 1.4 \\
\hline \hline
\end{tabular}

For $\mathrm{Cr}-1$, the influent concentrations of bicarbonate and chloride were 37 and $300 \mathrm{ppm}$, respectively, whereas in $\mathrm{Cr}-2$ they were $290 \mathrm{ppm}$ and $110 \mathrm{ppm}$, respectively. The concentration ratios $(\mathrm{Cr}-1 / \mathrm{Cr}-2)$ are 0.13 and 2.6 for bicarbonate and chloride, respectively. Since the resin is more selective toward chloride, the increase in chloride concentration offsets the decrease in bicarbonate concentration, causing breakthrough to occur sooner in the acidified water.

Our test with native MW-4 wellwater $(\mathrm{Cr}-6)$ showed that 4,860 bed volumes were treated before the effluent $\mathrm{Cr}$ concentration reached $11 \mathrm{ppb}$. Maureen Ridley and Roger Martinelli of LLNL's Environmental Restoration Division performed a similar experiment with A600 resin and MW-4 native wellwater. In the Ridley-Martinelli experiment:

- The water was not filtered or air stripped.

- A flow rate of $1 \mathrm{gpm} / \mathrm{ft}^{3}$ of resin bed was used for the bulk of the experiment; however, the flow rate was increased to $2 \mathrm{gpm} / \mathrm{ft}^{3}$ near the end of the experiment.

Ridley and Martinelli found that $43 \mathrm{~L}(6,140$ bed volumes) of water were treated before the effluent $\mathrm{Cr}$ concentration reached $11 \mathrm{ppb}$. This was disturbing, because the volume was $\sim 26 \%$ greater than the amount of water treated in $\mathrm{Cr}-6$. However, we measured the amount of resin they actually had in their column and found it to be $8.5 \mathrm{~mL}$ rather than $7.0 \mathrm{~mL}$. This means $43 / 0.0085=5,060$ bed volumes of water were treated, which is only $4 \%$ more than in $\mathrm{Cr}-6$. This suggests that $\mathrm{Cr}$ removal is not substantially affected over the range of flow rates ( 1 to $5 \mathrm{gpm} / \mathrm{ft}^{3}$ of resin bed) recommended by the supplier.

A proposed arrangement for the treatment facility has half the resin in service, while the other half is being regenerated. A facility operating at $60 \mathrm{gpm}$ with $60 \mathrm{ft}^{3}$ of resin requires half of the resin to be regenerated every 12.6 days.

Because other wells at LLNL show higher concentrations of Cr than MW-4, a means of predicting the resin performance as a function of $\mathrm{Cr}$ concentration would be useful. The water for experiments $\mathrm{Cr}-2$, $\mathrm{Cr}-5$, and $\mathrm{Cr}-6$ had identical anion compositions except for the influent $\mathrm{Cr}$ concentrations. Table 5 shows the total volume of water treated in these experiments before the effluent $\mathrm{Cr}$ concentration reached $11 \mathrm{ppb}$. 
Table 5. Total bed volumes of water treated before chromium breakthrough.

\begin{tabular}{c|c|c}
\hline \hline & $\begin{array}{c}\text { Influent Cr } \\
\text { (ppb) }\end{array}$ & Bed volumes \\
\hline Cr-6 & 35 & 4,860 \\
Cr-2 & 3,010 & 1,380 \\
Cr-5 & 35,600 & 334 \\
\hline \hline
\end{tabular}

An empirical model that fits the MW-4 data in Table 5 is:

$$
\mathrm{BV}=\frac{0.0593(\mathrm{Cr})^{-0.257}}{\left(\mathrm{SO}_{4}\right)+(\mathrm{Cr})}
$$

which relates the number of bed volumes treated before the effluent reaches $11 \mathrm{ppb} \mathrm{Cr}$ to the concentrations of sulfate and chromium (expressed in molarity). An implicit assumption in the use of a two-component model such as Eq. (5) is that the concentrations of bicarbonate, chloride, and nitrate only slightly perturb the sulfate/chromium equilibrium. Except for the fractional power $\mathrm{Cr}$ concentration dependence, Eq. (5) has the same form as Eq. (4). However, the bed volumes are not identical to the volume distribution coefficient, $D_{V} Y$, of Eq. (4). Rather than referring to a volume where the effluent concentration is a constant fraction of the influent concentration, the bed volumes refer to an absolute concentration of $11 \mathrm{ppb} \mathrm{Cr}$ in the effluent. The ratios of the $11 \mathrm{ppb} \mathrm{Cr}$ effluent to the influent concentrations are $0.31,3.6 \times 10^{-3}$, and $3.1 \times 10^{-4}$ for $\mathrm{Cr}-6,-2$, and -5 , respectively. Empirically, a power dependence on the influent $\mathrm{Cr}$ concentration seems to correct for the different extents of breakthrough in the three experiments.

Alternatively, we can fit the data directly to Eq. (4), but include a normalization factor, $N$, to correct the different extents of breakthrough:

$$
D_{V}^{Y}=\frac{K_{e q} R_{t}}{[X]+K_{e q}[Y]} N
$$

The data in Table 5 for MW-4 wellwater fit equally as well with $K_{e q}=3.04$, and $R_{t}=0.75 \mathrm{mmoles} \mathrm{Y}^{2}-/ \mathrm{mL}$ resin bed (from the suppliers specifications). The normalization factor is $N=1$ for the native wellwater and $N=0.38$ for the two experiments with spiked $\mathrm{Cr}$.

Clifford (1990) describes the use of strong base styrene-divinylbenzene anion resin to remove $\mathrm{Cr}(\mathrm{VI})$ from a Scottsdale, Ariz., well. The Arizona wellwater had the following characteristics: $\mathrm{pH}$ 7.6, $42 \mathrm{ppb} \mathrm{Cr}, 19 \mathrm{ppm} \mathrm{Ca}, 28 \mathrm{ppm} \mathrm{Mg}, 15 \mathrm{ppm} \mathrm{Si}, 244 \mathrm{ppm}$ bicarbonate, 24 ppm chloride, and $9 \mathrm{ppm}$ sulfate. The resin treated 20,700 bed volumes of water before the effluent reached $10 \mathrm{ppb}$. The performance predicted by Eq. (5) is 23,100 bed volumes to reach $11 \mathrm{ppb} \mathrm{Cr}$; the performance predicted by Eq. (6) is 19,000. Both models are equally good at predicting the results of the Scottsdale test. In both cases, since the Cr concentration is so low, the bed volumes scale linearly with the sulfate concentration.

Eq. (6) intuitively seems more reasonable. The magnitude of the selectivity coefficient, $K_{\text {eq }}$, for $\mathrm{Cr}$ with respect to sulfate is a reasonable one. However, we realize the futility of trying to choose a model with so little data. 


\section{Resin Regeneration}

One vendor recommended using sodium hydroxide to regenerate the resin, and even suggested that it was necessary for efficient regeneration. The vendor also suggested using the regenerated resin in the hydroxide form. We disagreed with these recommendations because:

- The resin has the least affinity for hydroxide of all the anions.

- The use of anion resin in the hydroxide form would undoubtedly cause the effluent $\mathrm{pH}$ to greatly exceed the upper $\mathrm{pH}$ discharge limit, since every anion removed from the water would be replaced by a hydroxide ion.

The results of $\mathrm{Cr}-3$ demonstrate that the hydroxide resin is not suitable for use in the treatment facility. The MW-4 effluent from such a resin has a $\mathrm{pH}$ of 12 . Furthermore, the flow rate fails catastrophically after only 89 bed volumes of water have been treated. Tests showed that the flow was blocked in the resin column and not in the gravity reservoir. A comparison of analytical data from $\mathrm{Cr}-3$ and $\mathrm{Cr}-6$ shows carbonate being held more strongly by the hydroxide-form resin. Furthermore, unlike the $\mathrm{Cl}$-form resin, the hydroxide-resin removes silica. Also in contrast to the behavior found with $\mathrm{Cl}$-resin, the effluent from the hydroxide-resin has a greatly reduced $\mathrm{Mg}$ concentration. The $\mathrm{Ca}$ concentration decreases gradually; however, it abruptly decreases just before the flow rate stops. The decreases in concentration of $\mathrm{Ca}$ and $\mathrm{Mg}$ are probably due to $\mathrm{CaCO}_{3}$ and $\mathrm{Mg}(\mathrm{OH})_{2}$ precipitation, although $\mathrm{Mg}$ and $\mathrm{Ca}$ silicates are also insoluble.

Table 6 summarizes our results from regenerating the columns used in $\mathrm{Cr}-4$ and -5 with $\mathrm{NaCl}$ alone. We regenerated the resin by adding separate $5-\mathrm{mL}$ portions of $1 \mathrm{M} \mathrm{NaCl}$ to the resin, until a total of five additions had been made. We allowed 30-minute contact times between each addition of $\mathrm{NaCl}$. Each addition corresponds to one equivalent of $\mathrm{NaCl}$ for each equivalent of exchange capacity. Flow rates through the resin were $0.3 \mathrm{~mL} / \mathrm{min}$, which corresponds to $0.6 \mathrm{gpm} / \mathrm{ft}^{3}$ of resin. (The supplier recommends regenerant flow rates of 0.2 to $0.5 \mathrm{gpm} / \mathrm{ft}^{3}$ of resin.)

The total recovery based on the influent $\mathrm{Cr}$ concentration and the total amount of water passed through the resin columns was $101 \%$ and $106 \%$, for $\mathrm{Cr}-4$ and $\mathrm{Cr}-5$, respectively.

From the data in Table 6, we conclude that regeneration with 3 equivalents of $\mathrm{NaCl}$ for each equivalent of resin is adequate for recovering $>98 \%$ of the Cr. Regenerating $30 \mathrm{ft}^{3}$ of resin with 3 equivalents of $1 \mathrm{M} \mathrm{NaCl}$ will produce a total of $1,010 \mathrm{gal}$ of $\mathrm{Cr}$-containing waste.

More concentrated $\mathrm{NaCl}$ can regenerate the resin adequately with less total volume of regenerant. We treated the resin used in $\mathrm{Cr}-6$ in two steps with $3.5 \mathrm{~mL}$ of $1.5 \mathrm{M} \mathrm{NaCl}$. Each addition corresponds to 1 equivalent of $\mathrm{NaCl}$ per resin equivalent. The total volume of waste from such a process is $50 \%$

Table 6. $\mathrm{Cr}$ recovery from the columns used in $\mathrm{Cr}-4$ and $\mathrm{Cr}-5$ in each regeneration step.

\begin{tabular}{c|cc|cc}
\hline Addition & $\begin{array}{c}\text { Cr-4 } \\
(\%)\end{array}$ & $\begin{array}{c}\text { Cumulative } \\
(\%)\end{array}$ & $\begin{array}{c}\text { Cr-5 } \\
(\%)\end{array}$ & $\begin{array}{c}\text { Cumulative } \\
(\%)\end{array}$ \\
\hline 1 & 2.2 & 2.2 & 22.1 & 22.1 \\
2 & 84.5 & 86.7 & 70.5 & 92.5 \\
3 & 11.7 & 98.4 & 5.7 & 98.3 \\
4 & 1.2 & 99.7 & 1.2 & 99.4 \\
5 & 0.3 & 100.0 & 0.6 & 100.0 \\
\hline \hline
\end{tabular}


less than using three additions of $1 \mathrm{M} \mathrm{NaCl}$. Table 7 summarizes our results. Flow rates through the resin were identical to those described previously. The total recoveries based on the influent $\mathrm{Cr}$ and sulfate concentrations were $105 \%$ and $91 \%$, respectively.

We conclude that when regenerating with 1 equivalent of $\mathrm{NaCl}$ per step, the efficiency of regenerating in two steps with $1.5 \mathrm{M} \mathrm{NaCl}$ is not significantly different from regenerating in three steps with $1.0 \mathrm{M} \mathrm{NaCl}$. For regenerating $30 \mathrm{ft}^{3}$ of resin, $450 \mathrm{gal}$ of $\mathrm{Cr}$-containing waste will be produced with $1.5 \mathrm{M} \mathrm{NaCl}$, whereas 1,010 gal will be produced with $1.0 \mathrm{M} \mathrm{NaCl}$.

Table 7. Regeneration of the column used in $\mathrm{Cr}-6$ with $1.5 \mathrm{M} \mathrm{NaCl}$.

\begin{tabular}{c|cc|cc}
\hline \hline Addition & $\begin{array}{c}\text { Cr } \\
(\%)\end{array}$ & $\begin{array}{c}\text { Cumulative } \\
(\%)\end{array}$ & $\begin{array}{c}\text { Sulfate } \\
(\%)\end{array}$ & $\begin{array}{c}\text { Cumulative } \\
(\%)\end{array}$ \\
\hline 1 & 12 & 12 & 72 & 72 \\
2 & 85 & 97 & 27 & 99 \\
Rinse & 2 & 99 & 0.3 & 99 \\
\hline \hline
\end{tabular}

\section{Recommendations}

- From a practical point of view, it is not important to be able to accurately model the column behavior at high (ppm) $\mathrm{Cr}$ influent levels, since LLNL waters have Cr concentrations that range from tens to hundreds of parts per billion. However, an experimental measurement with MW-4 wellwater containing $\sim 300 \mathrm{ppb} \mathrm{Cr}$ would be useful to validate the predicted performance of the resin. The choice of $\sim 300 \mathrm{ppb}$ would fill in the gap between $35 \mathrm{ppb}$ and $3,010 \mathrm{ppb}$. It could also help in determining whether Eq. (5), (6), or some other equation, is the correct model to use. Eqs. (5) and (6) predict that 2,780 and 1,800 bed volumes, respectively, of MW-4 wellwater with $300 \mathrm{ppb}$ Cr could be treated before the effluent reached $11 \mathrm{ppb} \mathrm{Cr}$.

- Well P-701 will be the initial source of water for Treatment Facility C; wells MW-351 and MW-361 are candidates for remediation at Treatment Facility D. Results of anion analyses of these waters are shown in Table 8. In particular, MW-351 has twice the sulfate concentration of $\mathrm{MW}-4$. Assuming the same initial $\mathrm{Cr}$ concentration, Eq. (4) predicts the A600 resin could treat 2,490 bed volumes. Therefore, a facility treating MW-351 water would require half the resin to be regenerated every 6.5 days.

- The Arizona study by Clifford (1990) found that a macroporous resin treated $65 \%$ more water than the comparable gel resin before $\mathrm{Cr}$ breakthrough occurred. If the regeneration frequency

Table 8. Anion concentrations in LLNL wells.

\begin{tabular}{c|c|c|c|c}
\hline \hline Well No. & $\begin{array}{c}\mathrm{HCO}_{3}^{-} \\
(\mathrm{ppm})\end{array}$ & $\begin{array}{c}\mathrm{Cl}^{-} \\
(\mathrm{ppm})\end{array}$ & $\begin{array}{c}\mathrm{NO}_{3}^{-} \\
(\mathrm{ppm})\end{array}$ & $\begin{array}{c}\mathrm{SO}_{4}^{2-} \\
\left(\mathrm{ppm}^{2}\right.\end{array}$ \\
\hline MW-4 & 360 & 110 & 22 & 45 \\
MW-351 & 250 & 73 & 25 & 88 \\
MW-361 & 520 & 110 & 45 & 20 \\
P-701 & 400 & 95 & 24 & 35 \\
\hline \hline
\end{tabular}


required by $\mathrm{A} 600$ resin is too short, the use of a macroporous resin might be beneficial. However, the macroporous resin was more difficult to regenerate than the gel resin. They recovered $89 \%$ of the $\mathrm{Cr}$ from a gel-type resin with 3.1 equivalents of $1 \mathrm{M} \mathrm{NaCl}$. However, they recovered only $67 \%$ of the $\mathrm{Cr}$ from a macroporous resin with 3.6 equivalents of $1 \mathrm{M}$ $\mathrm{NaCl}$.

\section{References}

Clifford, D. A. (1990), in Water Quality and Treatment, Chapter 9, Ed. 4, Pontius, F. Ed., McGraw Hill, New York.

Marhol, M. (1982), "Ion Exchangers in Analytical Chemistry. Their Properties and Use in Inorganic Chemistry," in Vol.XIV of Wilson and Wilson's Comprehensive Analytical Chemistry, Svehla, G., Ed., Elsevier, New York.

\section{Acknowledgments}

The author thanks Bea Armstrong, Nora Butler-Briant, Terry Duewer, Ken King, Pat Perry, Bob Reibold, and Mike Sharp of the Analytical Sciences Division, LLNL, and Roger Martinelli of the Environmental Restoration Division, LLNL, for chemical analyses that supported this work. 


\section{Appendix A}


Appendix Table 1. Data from experiments with A600 resin.

\begin{tabular}{cccc}
\hline \hline Experiment & $\begin{array}{c}\mathrm{Cr} \\
(\mathrm{ppb})\end{array}$ & $\begin{array}{c}\mathrm{pH} \\
\text { adjustment }\end{array}$ & $\begin{array}{c}\text { Resin } \\
\text { form }\end{array}$ \\
\hline Cr-1 & 3,100 & Yes & Chloride \\
Cr-2 & 3,010 & No & Chloride \\
Cr-3 & 32 & No & Hydroxide \\
Cr-4 & 35,600 & No & Chloride \\
Cr-5 & 35,600 & No & Chloride \\
Cr-6 & 35 & No & Chloride \\
Cr-7 & 3,010 & No & Sulfate \\
\hline \hline
\end{tabular}


Appendix Table 2. Analytical data for $\mathrm{Cr}-1$ experiment.

\begin{tabular}{|c|c|c|c|c|c|c|c|c|c|c|c|}
\hline Sample & Bed vol. & $\begin{array}{c}\text { Rate } \\
\text { (g/min) }\end{array}$ & $\mathbf{p H}$ & $\begin{array}{c}\mathrm{Cr} \\
(\mathrm{ppb})\end{array}$ & $\begin{array}{c}\mathrm{Ca} \\
(\mathrm{ppm})\end{array}$ & $\begin{array}{c}\mathbf{M g} \\
\text { (ppm) }\end{array}$ & $\begin{array}{c}\mathrm{Si} \\
\text { (ppm) }\end{array}$ & $\begin{array}{c}\mathrm{CO}_{3} \\
(\mathrm{ppm})\end{array}$ & $\begin{array}{c}\mathrm{Cl} \\
\text { (ppm) }\end{array}$ & $\begin{array}{c}\mathrm{NO}_{3} \\
\text { (ppm) }\end{array}$ & $\begin{array}{c}\mathrm{SO}_{4} \\
\text { (ppm) }\end{array}$ \\
\hline 1001 & 0 & $\mathbf{0}$ & 8.0 & 3098 & 61.7 & 21.8 & 15.5 & 36.7 & 295 & 21.8 & 44.4 \\
\hline 1101 & 7 & 0.795 & 5.1 & 0 & 62.2 & 21.7 & 14.7 & 1.7 & 374 & 0.0 & 0.0 \\
\hline 1102 & 12 & 0.638 & 5.6 & $\mathbf{0}$ & & & & & & & \\
\hline 1103 & 20 & 0.730 & 6.1 & 0 & & & & 2.4 & & & \\
\hline 1104 & 28 & 0.764 & 6.7 & 2 & & & & 5.4 & & & \\
\hline 1105 & 37 & 0.725 & 7.3 & $\mathbf{0}$ & & & & 12.1 & & & \\
\hline 1106 & 46 & 1.135 & 7.6 & 3 & & & & 20.5 & & & \\
\hline 1107 & 56 & 1.163 & 7.7 & $\mathbf{0}$ & & & & & & & \\
\hline 1108 & 65 & 1.162 & 7.8 & 0 & & & & & & & \\
\hline 1109 & 75 & 1.169 & 7.9 & $\mathbf{0}$ & & & & & & & \\
\hline 1110 & 84 & 1.162 & 8.0 & 0 & 62.4 & 22.1 & 15.5 & 0.0 & 350 & 0.0 & 0.0 \\
\hline 1111 & 93 & 1.172 & & $\mathbf{0}$ & & & & & & & \\
\hline 1112 & 103 & 1.165 & & 4 & & & & 35.3 & & & \\
\hline 1113 & 112 & 1.169 & . & 0 & & & & & & & \\
\hline 1114 & 121 & 1.165 & & 0 & & & & & & & \\
\hline 1115 & 131 & 1.165 & 8.0 & 0 & & & & 36.5 & & & \\
\hline 1116 & 140 & 1.165 & & 0 & & & & & & & \\
\hline 1117 & 149 & 1.165 & & 0 & & & & & & & \\
\hline 1118 & 159 & 1.165 & & 2 & & & & & & & \\
\hline 1119 & 170 & 1.369 & & 0 & & & & 38.3 & & & \\
\hline 1120 & 179 & 1.175 & 8.0 & 2 & 61.7 & 22.2 & 15.3 & & 345 & 0.0 & 0.0 \\
\hline 1121 & 188 & 1.177 & & 0 & & & & & & & \\
\hline 1122 & 198 & 1.173 & & 0 & & & & & & & \\
\hline 1123 & 207 & 1.172 & & 0 & & & & & & & \\
\hline 1124 & 216 & 1.175 & & 2 & & & & 38.3 & & & \\
\hline
\end{tabular}


Appendix Table 2. (Continued)

\begin{tabular}{|c|c|c|c|c|c|c|c|c|c|c|c|}
\hline Sample & Bed vol. & $\begin{array}{c}\text { Rate } \\
(\mathrm{g} / \mathrm{min})\end{array}$ & pH & $\begin{array}{c}\mathrm{Cr} \\
(\mathrm{ppb})\end{array}$ & $\begin{array}{c}\mathrm{Ca} \\
(\mathrm{ppm})\end{array}$ & $\begin{array}{c}\mathbf{M g} \\
\text { (ppm) }\end{array}$ & $\begin{array}{c}\mathrm{Si} \\
(\mathrm{ppm})\end{array}$ & $\begin{array}{c}\mathrm{CO}_{3} \\
(\mathrm{ppm})\end{array}$ & $\begin{array}{c}\mathrm{Cl} \\
\text { (ppm) }\end{array}$ & $\begin{array}{c}\mathrm{NO}_{3} \\
\text { (ppm) }\end{array}$ & $\begin{array}{r}\mathrm{SO}_{4} \\
(\mathrm{ppm})\end{array}$ \\
\hline 1125 & 226 & 1.170 & 8.0 & 0 & & & & & & & \\
\hline 1126 & 235 & 1.173 & & 0 & & & & & . & & \\
\hline 1127 & 245 & 1.168 & & 0 & & & & & & & \\
\hline 1128 & 254 & 1.171 & & 0 & & & & & & & \\
\hline $1129^{\circ}$ & 263 & 1.170 & & 0 & & & & 38.8 & & & \\
\hline 1130 & 273 & 1.165 & 8.0 & 0 & 62.9 & 22.0 & 15.7 & & 345 & 2.1 & 0.0 \\
\hline 1201 & 295 & 1.067 & 8.0 & 0 & & & & & & & \\
\hline 1202 & 319 & 1.148 & & 0 & & & & & & & \\
\hline 1203 & 343 & 1.146 & & 0 & & & & & & & \\
\hline 1204 & 367 & 1.144 & 8.0 & 0 & 62.5 & 22.0 & 15.6 & 38.0 & 340 & 12.3 & 0.0 \\
\hline 1205 & 392 & 1.159 & & 0 & & & & & & & \\
\hline 1206 & 416 & 1.148 & & 0 & & & & & & & \\
\hline 1207 & 440 & 1.149 & & 0 & & & & & & & \\
\hline 1208 & 466 & 1.236 & & 0 & 62.1 & 21.7 & 15.5 & 36.9 & 327 & 30.1 & 2.4 \\
\hline 1209 & 491 & 1.171 & & 0 & & & & & & & \\
\hline 1210 & 516 & 1.167 & & 0 & & & & & & & \\
\hline 1211 & 540 & 1.164 & & 0 & & & & & & & \\
\hline 1212 & 565 & 1.160 & & 0 & 62.0 & 21.7 & 15.4 & 36.9 & 329 & 33.5 & 17.2 \\
\hline 1213 & 590 & 1.164 & & 0 & & & & & & & \\
\hline 1301 & 625 & 1.155 & & $\mathbf{0}$ & & & & & & & \\
\hline 1302 & 661 & 1.154 & & 2 & 62.3 & 21.8 & 15.5 & 37.0 & 304 & 27.9 & 40.9 \\
\hline 1303 & 697 & 1.152 & & 0 & & & & & & & \\
\hline 1304 & 734 & 1.152 & & 3 & & & & & & & \\
\hline 1305 & 770 & 1.158 & & 4 & 62.2 & 21.8 & 15.4 & 37.1 & 309 & 24.6 & 48.0 \\
\hline
\end{tabular}


Appendix Table 2. (Continued)

\begin{tabular}{|c|c|c|c|c|c|c|c|c|c|c|c|}
\hline Sample & Bed vol. & $\begin{array}{c}\begin{array}{c}\text { Rate } \\
(\mathrm{g} / \mathrm{min})\end{array} \\
\end{array}$ & $\mathbf{p H}$ & $\begin{array}{c}\mathrm{Cr} \\
(\mathrm{ppb})\end{array}$ & $\begin{array}{c}\mathrm{Ca} \\
(\mathrm{ppm})\end{array}$ & $\begin{array}{c}\mathbf{M g} \\
\text { (ppm) }\end{array}$ & $\begin{array}{c}\mathbf{S i} \\
(\mathbf{p p m})\end{array}$ & $\begin{array}{c}\mathrm{CO}_{3} \\
(\mathrm{ppm})\end{array}$ & $\underset{(\mathrm{ppm})}{\mathrm{Cl}}$ & $\begin{array}{c}\mathrm{NO}_{3} \\
\text { (ppm) }\end{array}$ & $\begin{array}{c}\mathrm{SO}_{4} \\
(\mathrm{ppm})\end{array}$ \\
\hline 1306 & 808 & 1.176 & & 5 & & & & & & & \\
\hline 1307 & 845 & 1.169 & & 7 & & & & & & & \\
\hline 1308 & 881 & 1.141 & & 8 & 63.0 & 22.1 & 15.7 & 37.5 & 305 & 24.8 & 49.6 \\
\hline 1309 & 918 & 1.165 & & 10 & & & & & & & \\
\hline 1310 & 955 & 1.182 & & 11 & & & & 37.6 & & & \\
\hline 1311 & 970 & 1.184 & & 11 & 60.3 & 21.1 & 15.0 & & 300 & 24.1 & 47.2 \\
\hline
\end{tabular}


Appendix Table 3. Analytical data for $\mathrm{Cr}$-2 experiment.

\begin{tabular}{|c|c|c|c|c|c|c|c|c|c|c|c|}
\hline Sample & Bed vol. & $\begin{array}{c}\text { Rate } \\
\text { (g/min) }\end{array}$ & $\mathbf{p H}$ & $\begin{array}{c}\mathrm{Cr} \\
(\mathrm{ppb})\end{array}$ & $\begin{array}{c}\mathrm{Ca} \\
\text { (ppm) }\end{array}$ & $\begin{array}{c}\mathbf{M g} \\
(\mathrm{ppm})\end{array}$ & $\begin{array}{c}\text { Si } \\
\text { (ppm) }\end{array}$ & $\begin{array}{c}\mathrm{CO}_{3} \\
\text { (ppm) }\end{array}$ & $\begin{array}{c}\mathrm{Cl} \\
(\mathrm{ppm})\end{array}$ & $\begin{array}{c}\mathrm{NO}_{3} \\
\text { (ppm) }\end{array}$ & $\begin{array}{c}\mathrm{SO}_{4} \\
\text { (ppm) }\end{array}$ \\
\hline 1902 & 0 & 0 & 9.1 & 2980 & 60.0 & 22.5 & 15.6 & 290 & & & \\
\hline 2601 & 0 & 0 & 8.9 & 3070 & 43.7 & 23.1 & 15.9 & 287 & & & \\
\hline 2001 & 36 & 1.150 & 7.0 & 3 & 59.2 & 22.9 & 15.5 & 24 & 369 & 0.0 & 0.0 \\
\hline 2002 & 73 & 1.156 & 7.5 & 0 & 59.6 & 23.4 & 15.9 & 136 & . & & \\
\hline 2003 & 110 & 1.156 & 7.7 & 0 & 38.3 & 23.2 & 15.9 & 225 & & & \\
\hline 2004 & 147 & 1.160 & 8.0 & 0 & & & & 273 & 205 & 0.0 & 0.0 \\
\hline 2005 & 183 & 1.156 & 8.2 & 0 & 41.3 & 22.8 & 15.7 & & & . & \\
\hline 2006 & 220 & 1.146 & 8.3 & 0 & & & & & & & \\
\hline 2007 & 255 & 1.129 & 8.4 & 0 & 39.0 & 22.6 & 15.6 & 297 & 166 & 0.0 & 0.0 \\
\hline 2008 & 290 & 1.105 & 8.4 & 0 & & & & & & & \\
\hline 2009 & 313 & 1.086 & 8.5 & 0 & & & & & & & \\
\hline 2101 & 348 & 1.099 & 8.5 & 0 & & & & 286 & 153 & 0.9 & 0.0 \\
\hline 2102 & 382 & 1.061 & & 0 & & & & & & & \\
\hline 2103 & 414 & 1.027 & 8.5 & 0 & 28.9 & 22.5 & 15.7 & & & & \\
\hline 2104 & 446 & 1.001 & & 0 & & & & & 130 & 9.4 & 0.0 \\
\hline 2105 & 477 & 0.979 & 8.6 & 0 & & & & & & & \\
\hline 2106 & 510 & 0.975 & & 0 & & & & & & & \\
\hline 2107 & 545 & 0.950 & 8.6 & 0 & 34.0 & 22.7 & 15.6 & & 126 & 26.4 & 0.0 \\
\hline 2108 & 581 & 0.927 & & 0 & & & & & & & \\
\hline 2109 & 617 & 0.922 & 8.7 & 0 & & & & & & & \\
\hline 2110 & 652 & 0.907 & & 0 & & & & & 122 & 34.7 & 5.4 \\
\hline 2111 & 686 & 0.883 & 8.7 & 0 & & & & & & & \\
\hline 2201 & 720 & 0.892 & & 0 & 37.8 & 22.2 & 15.2 & & & & \\
\hline 2202 & 754 & 0.881 & 8.7 & 0 & & & & 281 & 114 & 29.6 & 30.6 \\
\hline 2203 & 787 & 0.840 & & 0 & & & & & & & \\
\hline
\end{tabular}


Appendix Table 3. (Continued)

\begin{tabular}{|c|c|c|c|c|c|c|c|c|c|c|c|}
\hline Sample & Bed vol. & $\begin{array}{c}\text { Rate } \\
\text { (g/min) }\end{array}$ & $\mathbf{p H}$ & $\begin{array}{c}\mathrm{Cr} \\
(\mathrm{ppb}) \\
\end{array}$ & $\begin{array}{c}\text { Ca } \\
\text { (ppm) }\end{array}$ & $\begin{array}{c}\mathrm{Mg} \\
\text { (ppm) }\end{array}$ & $\begin{array}{c}\text { Si } \\
\text { (ppm) }\end{array}$ & $\begin{array}{c}\mathrm{CO}_{3} \\
(\mathrm{ppm})\end{array}$ & $\begin{array}{c}\mathrm{Cl} \\
\text { (ppm) }\end{array}$ & $\begin{array}{c}\mathrm{NO}_{3} \\
\text { (ppm) }\end{array}$ & $\begin{array}{r}\mathrm{SO}_{4} \\
\text { (ppm) }\end{array}$ \\
\hline 2204 & 817 & 0.781 & 8.7 & 0 & & & & & & & \\
\hline 2205 & 850 & 0.296 & 8.7 & 0 & & & & & 113 & 24.2 & 45.0 \\
\hline 2206 & 856 & 0.179 & & 0 & 24.1 & 22.2 & 15.5 & & & & \\
\hline 2701 & 883 & 1.171 & & 0 & 42.1 & 22.7 & 15.5 & & 115 & 24.6 & 47.9 \\
\hline 2702 & 919 & 1.169 & 8.6 & 0 & & & & & & & \\
\hline 2703 & 955 & 1.169 & 8.6 & 0 & & & & & & & \\
\hline 2704 & 991 & 1.168 & & 0 & 41.7 & 23.0 & 15.8 & & 112 & 23.7 & 49.9 \\
\hline 2705 & 1027 & 1.173 & 8.7 & 2 & & & & & & & \\
\hline 2706 & 1063 & 1.169 & 8.6 & 2 & & & & & & & \\
\hline 2707 & 1099 & 1.161 & & 2 & 41.5 & 22.9 & 15.7 & & 113 & 23.7 & 48.8 \\
\hline 2708 & 1131 & 0.994 & 8.6 & 3 & & & & & & & \\
\hline 2801 & 1164 & 0.966 & 8.6 & 3 & & & & & & & \\
\hline 2802 & 1204 & 0.706 & $\ldots$ & 2 & 36.8 & 21.2 & 14.6 & 261 & 105 & 21.6 & 44.8 \\
\hline 2803 & 1239 & 0.263 & 8.7 & 2 & & & & & & & \\
\hline 3301 & 1264 & 1.214 & & 5 & 25.0 & 22.4 & 15.5 & & & & \\
\hline 3302 & 1299 & 1.168 & & 6 & & & & & & & \\
\hline 3303 & 1334 & 1.166 & & 7 & & & & & & & \\
\hline 3304 & 1354 & 1.168 & & 9 & 22.9 & 22.3 & 15.6 & & & & \\
\hline
\end{tabular}


Appendix Table 4. Analytical data for $\mathrm{Cr}$-3 experiment.

\begin{tabular}{|c|c|c|c|c|c|c|c|c|c|c|c|}
\hline Sample & Bed vol. & $\begin{array}{c}\text { Rate } \\
\text { (g/min) }\end{array}$ & pH & $\begin{array}{c}\mathrm{Cr} \\
(\mathrm{ppb})\end{array}$ & $\underset{(\mathrm{ppm})}{\mathrm{Ca}}$ & $\underset{(\mathbf{p p m})}{\mathbf{M g}}$ & $\begin{array}{c}\mathbf{S i} \\
(\mathbf{p p m})\end{array}$ & $\begin{array}{c}\mathrm{CO}_{3} \\
(\mathrm{ppm})\end{array}$ & $\begin{array}{c}\mathrm{Cl} \\
(\text { ppm) }\end{array}$ & $\begin{array}{c}\mathrm{NO}_{3} \\
(\mathrm{ppm})\end{array}$ & $\begin{array}{c}\mathrm{SO}_{4} \\
(\mathrm{ppm})\end{array}$ \\
\hline 4101 & 0 & o & 8.9 & 32 & 53.5 & 24.0 & 16.4 & 288.3 & 116 & 22.0 & 46.1 \\
\hline 4102 & 10 & 1.175 & 12.1 & 0 & 45.9 & 3.0 & 0.0 & 1.9 & 1 & 0.0 & 0.0 \\
\hline 4103 & 19 & 1.140 & 12.2 & $\mathbf{0}$ & 47.4 & 1.5 & 0.0 & & & & \\
\hline 4104 & 28 & 1.154 & 12.2 & 0 & 44.1 & 1.9 & 0.0 & 2.8 & 1 & 0.0 & 0.0 \\
\hline 4105 & 37 & 1.133 & 12.2 & o & 39.8 & 1.8 & 0.0 & & & & \\
\hline 4106 & 47 & 1.147 & 12.2 & o & 38.2 & 1.8 & 0.0 & 3.1 & 1 & 0.0 & 0.0 \\
\hline 4107 & 57 & 1.251 & 12.2 & 0 & 36.8 & 2.6 & 0.0 & 2.9 & 1 & 0.0 & 0.0 \\
\hline 4108 & 66 & 1.147 & 12.1 & 0 & 35.1 & 3.0 & 0.0 & & & & \\
\hline 4109 & 75 & 1.101 & 12.0 & 0 & 6.9 & 3.1 & 0.5 & 23.3 & $\mathbf{1}$ & 0.0 & 0.0 \\
\hline 4110 & 82 & 0.943 & 11.9 & 0 & 4.9 & 2.9 & 1.3 & 31.8 & & & \\
\hline 4111 & 89 & 0.414 & 11.4 & 0 & 4.5 & 2.1 & 6.5 & & 11 & 0.0 & 0.0 \\
\hline
\end{tabular}


Appendix Table 5. Analytical data for Cr-4 experiment.

\begin{tabular}{|c|c|c|c|c|c|c|c|c|c|c|c|}
\hline Sample & Bed vol. & $\begin{array}{c}\text { Rate } \\
\text { (g/min) }\end{array}$ & $\mathbf{p H}$ & $\begin{array}{c}\mathrm{Cr} \\
(\mathrm{ppb})\end{array}$ & $\begin{array}{c}\mathrm{Ca} \\
\text { (ppm) }\end{array}$ & $\begin{array}{c}\mathbf{M g} \\
(\mathbf{p p m})\end{array}$ & $\begin{array}{c}\mathbf{S i} \\
(\mathbf{p p m})\end{array}$ & $\begin{array}{c}\mathrm{CO}_{3} \\
(\mathrm{ppm})\end{array}$ & $\begin{array}{c}\mathrm{Cl} \\
\text { (ppm) }\end{array}$ & $\begin{array}{c}\mathrm{NO}_{3} \\
(\mathrm{ppm})\end{array}$ & $\begin{array}{c}\mathrm{SO}_{4} \\
(\mathrm{ppm})\end{array}$ \\
\hline 4204 & 0 & 0 & 9.0 & 35600 & 44.2 & 23.2 & 15.9 & 259.3 & & & \\
\hline 4301 & 7 & 1.136 & 4.4 & & & & & & & & \\
\hline 4302 & 14 & 1.154 & 5.4 & 0 & & & & & & & \\
\hline 4303 & 22 & 1.168 & 6.5 & & & & & & & & \\
\hline 4304 & 29 & 1.161 & 7.3 & 0 & & & & & & & \\
\hline 4305 & 36 & 1.166 & 7.5 & & & & & & & & \\
\hline 4306 & 44 & 1.166 & 7.7 & 0 & & & & & & & \\
\hline 4307 & 51 & 1.177 & 7.8 & & & & & & & & \\
\hline 4308 & 58 & 1.173 & 7.8 & 0 & & & & & & & \\
\hline 4309 & 66 & 1.132 & 7.9 & & & & & & & & \\
\hline 4310 & 73 & 1.132 & 8.1 & 0 & & & & & & & \\
\hline 4311 & 80 & 1.214 & 8.2 & & & & & & & & \\
\hline 4312 & 88 & 1.173 & 8.1 & 0 & & & & & & & \\
\hline 4313 & 95 & 1.214 & 8.3 & & & & & & & & \\
\hline 4314 & 103 & 1.223 & 8.2 & 0 & & & & & & & \\
\hline 4315 & 110 & 1.164 & 8.3 & & & & & & & & \\
\hline 4316 & 118 & 1.159 & 8.3 & $\mathbf{0}$ & & & & & & & \\
\hline 4317 & 125 & 1.164 & 8.3 & & & & & & & & \\
\hline 4318 & 132 & 1.164 & 8.4 & 0 & & & & & & & \\
\hline 4319 & 140 & 1.168 & 8.3 & & & & & & & & \\
\hline 4320 & 147 & 1.168 & 8.4 & 0 & & & & & & & \\
\hline 4321 & 154 & 1.168 & 8.5 & & & & & & & & \\
\hline 4322 & 162 & 1.168 & 8.4 & 0 & & & & & & & \\
\hline 4323 & 169 & 1.168 & 8.4 & & & & & & & & \\
\hline 4324 & 176 & 1.168 & 8.5 & 0 & & & & & & & \\
\hline
\end{tabular}


Appendix Table 5. (Continued)

\begin{tabular}{|c|c|c|c|c|c|c|c|c|c|c|c|}
\hline Sample & Bed vol. & $\begin{array}{c}\text { Rate } \\
\text { (g/min) }\end{array}$ & pH & $\begin{array}{c}\mathrm{Cr} \\
(\mathrm{ppb})\end{array}$ & $\underset{(\mathrm{ppm})}{\mathrm{Ca}}$ & $\underset{\text { (ppm) }}{\mathbf{M g}}$ & $\begin{array}{c}\mathbf{S i} \\
(\mathbf{p p m})\end{array}$ & $\begin{array}{c}\mathrm{CO}_{3} \\
(\mathrm{ppm})\end{array}$ & $\underset{(\mathrm{ppm})}{\mathrm{Cl}}$ & $\begin{array}{c}\mathrm{NO}_{3} \\
\text { (ppm) }\end{array}$ & $\begin{array}{r}\mathrm{SO}_{4} \\
(\mathrm{ppm})\end{array}$ \\
\hline 4325 & 184 & 1.168 & 8.5 & & & & & & & & \\
\hline 4326 & 191 & 1.168 & 8.5 & $\mathbf{0}$ & & & & & & & \\
\hline 4327 & 198 & 1.168 & 8.6 & & & & & & & . & \\
\hline 4328 & 206 & 1.164 & 8.6 & 0 & & & & & & & \\
\hline
\end{tabular}


Appendix Table 6. Analytical data for $\mathrm{Cr}-5$ experiment.

\begin{tabular}{|c|c|c|c|c|c|c|c|c|c|c|c|}
\hline Sample & Bed vol. & $\begin{array}{c}\text { Rate } \\
\text { (g/min) }\end{array}$ & $\mathrm{pH}$ & $\begin{array}{c}\mathrm{Cr} \\
(\mathrm{ppb})\end{array}$ & $\begin{array}{c}\mathrm{Ca} \\
(\mathrm{ppm})\end{array}$ & $\begin{array}{c}\mathbf{M g} \\
\text { (ppm) }\end{array}$ & $\begin{array}{c}\mathbf{S i} \\
(\mathrm{ppm})\end{array}$ & $\begin{array}{c}\mathrm{CO}_{3} \\
(\mathrm{ppm})\end{array}$ & $\begin{array}{c}\mathrm{Cl} \\
(\mathrm{ppm})\end{array}$ & $\begin{array}{c}\mathrm{NO}_{3} \\
\text { (ppm) }\end{array}$ & $\begin{array}{c}\mathrm{SO}_{4} \\
\text { (ppm) }\end{array}$ \\
\hline 4204 & 0 & 0 & 9.0 & 35600 & 44.2 & 23.2 & 15.9 & 259.3 & & & \\
\hline 4901 & 18 & 1.153 & 7.1 & 2 & 42.5 & 22.4 & 14.8 & 5.8 & & & \\
\hline 4902 & 37 & 1.151 & 7.5 & 0 & & & & & & & \\
\hline 4903 & 55 & 1.142 & 7.7 & 0 & & & & & & & \\
\hline 4904 & 75 & 1.213 & 7.9 & 0 & 42.4 & 23.2 & 15.7 & 156.8 & & & \\
\hline 4905 & 93 & 1.136 & 8.0 & 0 & & & & & & & \\
\hline 4906 & 111 & 1.147 & 8.0 & 0 & & & & & & & \\
\hline 4907 & 130 & 1.153 & 8.1 & 0 & & & & & & & \\
\hline 4908 & 149 & 1.213 & 8.2 & $\mathbf{0}$ & 40.7 & 23.1 & 15.6 & 247.4 & & & \\
\hline 4909 & 168 & 1.174 & 8.5 & 0 & & & & & & & \\
\hline 4910 & 186 & 1.171 & 8.5 & 0 & & & & & & & \\
\hline 4911 & 205 & 1.164 & 8.5 & 0 & & & & 257.1 & & & \\
\hline 4912 & 223 & 1.136 & 8.5 & 0 & 35.8 & 22.9 & 15.6 & & & & \\
\hline 4913 & 242 & 1.191 & 8.5 & 2 & & & & & & & \\
\hline 4914 & 261 & 1.194 & 8.6 & $\mathbf{0}$ & & & & & & & \\
\hline 5001 & 280 & 1.179 & 8.7 & 3 & & & & & & & \\
\hline 5002 & 298 & 1.162 & 8.7 & 3 & 33.2 & 22.9 & 15.6 & 278.0 & & & \\
\hline 5003 & 316 & 1.171 & 8.8 & 9 & & & & & & & \\
\hline 5004 & 334 & 1.172 & 8.9 & 11 & 28.7 & 22.8 & 15.6 & & & & \\
\hline 5005 & 352 & 1.167 & 9.0 & 22 & & & & & & & \\
\hline 5006 & 370 & 1.166 & 9.1 & 29 & & & & & & & \\
\hline 5007 & 388 & 1.168 & 9.1 & 47 & & & & & & & \\
\hline 5008 & 406 & 1.171 & 9.1 & 61 & 24.4 & 23.0 & 15.8 & & & & \\
\hline
\end{tabular}


Appendix Table 7. Analytical data for $\mathrm{Cr}-6$ experiment.

\begin{tabular}{|c|c|c|c|c|c|c|c|c|c|c|c|}
\hline Sample & Bed vol. & $\begin{array}{c}\text { Rate } \\
\text { (g/min) }\end{array}$ & pH & $\begin{array}{c}\mathrm{Cr} \\
(\mathrm{ppb})\end{array}$ & $\begin{array}{c}\mathrm{Ca} \\
(\mathbf{p p m})\end{array}$ & $\underset{(\mathbf{p p m})}{\mathbf{M g}}$ & $\begin{array}{c}\mathbf{S i} \\
(\mathbf{p p m})\end{array}$ & $\begin{array}{c}\mathrm{CO}_{3} \\
(\mathrm{ppm})\end{array}$ & $\begin{array}{c}\mathrm{Cl} \\
\text { (ppm) }\end{array}$ & $\begin{array}{c}\mathrm{NO}_{3} \\
\text { (ppm) }\end{array}$ & $\underset{(\mathrm{ppm})}{\mathrm{SO}_{4}}$ \\
\hline 5502 & 0 & 0 & 9.1 & 35 & 43.8 & 23.7 & 16.1 & 252.8 & 114 & 23.9 & 44.3 \\
\hline 6800 & o & 0.000 & & 34 & 37.7 & 23.7 & 16.1 & 264.4 & 115 & 25.3 & 45.0 \\
\hline 5503 & 9 & 2.197 & 4.6 & o & 50.9 & 22.5 & 14.7 & & 339 & 0.0 & 0.0 \\
\hline 5504 & 19 & 2.292 & 6.4 & 0 & & & & 6.3 & & & \\
\hline 5505 & 30 & 2.298 & 7.1 & 0 & & & & & & & \\
\hline 5506 & 50 & 2.311 & 7.6 & $\mathbf{0}$ & 56.0 & 24.0 & 16.3 & & & & \\
\hline 5507 & 69 & 2.311 & 7.8 & $\mathbf{0}$ & & & & 117.5 & 284 & 0.0 & 0.0 \\
\hline 5508 & 89 & 2.315 & 8.0 & o & & & & & & & \\
\hline 5509 & 121 & 2.300 & 8.1 & $\mathbf{0}$ & & & & & & & \\
\hline 5510 & 152 & 2.311 & 8.3 & 0 & 47.4 & 23.8 & 16.1 & 226.6 & 200 & 0.0 & 0.0 \\
\hline 5511 & 184 & 2.298 & 8.3 & 0 & & & & & & & \\
\hline 5512 & 215 & 2.272 & 8.5 & 0 & & & & 236.1 & 171 & 0.0 & 0.0 \\
\hline 5513 & 247 & 2.326 & 8.5 & 0 & & & & & & & \\
\hline 5514 & 279 & 2.334 & 8.5 & 0 & 35.0 & 23.0 & 15.9 & & 155 & 0.0 & 0.0 \\
\hline 5515 & 311 & 2.327 & 8.5 & o & & & & 252.1 & & & \\
\hline 5516 & 342 & 2.296 & 8.6 & 0 & & & & & & & \\
\hline 5517 & 373 & 2.262 & 8.6 & o & 30.6 & 23.2 & 16.0 & & & & \\
\hline 5518 & 405 & 2.313 & 8.6 & $\mathbf{0}$ & & & & & 138 & 2.8 & 0.0 \\
\hline 5601 & 471 & 2.293 & 8.7 & o & & & & & & & \\
\hline 5602 & 536 & 2.295 & 8.8 & 0 & 28.8 & 23.2 & 15.9 & & 131 & 8.4 & 0.0 \\
\hline 5603 & 601 & 2.280 & 8.8 & 0 & & & & & & & \\
\hline 5604 & 668 & 2.325 & 8.7 & 0 & & & & & & & \\
\hline 5605 & 722 & 2.267 & 8.7 & o & 30.5 & 23.4 & 16.1 & & 126 & 28.1 & 4.0 \\
\hline 5606 & 894 & 2.290 & 8.7 & 0 & & & & & 124 & 34.2 & 12.2 \\
\hline $5701^{\circ}$ & 1030 & 2.276 & 8.6 & 0 & & & & & 116 & 28.9 & 32.6 \\
\hline
\end{tabular}


Appendix Table 7. (Continued)

\begin{tabular}{|c|c|c|c|c|c|c|c|c|c|c|c|}
\hline Sample & Bed vol. & $\begin{array}{c}\text { Rate } \\
\text { (g/min) }\end{array}$ & pH & $\begin{array}{c}\mathrm{Cr} \\
(\mathrm{ppb})\end{array}$ & $\begin{array}{c}\mathrm{Ca} \\
(\mathrm{ppm})\end{array}$ & $\begin{array}{c}\mathrm{Mg} \\
\text { (ppm) }\end{array}$ & $\begin{array}{c}\text { Si } \\
\text { (ppm) }\end{array}$ & $\begin{array}{c}\mathrm{CO}_{3} \\
(\mathrm{ppm})\end{array}$ & $\begin{array}{c}\mathrm{Cl} \\
\text { (ppm) }\end{array}$ & $\begin{array}{c}\mathrm{NO}_{3} \\
\text { (ppm) }\end{array}$ & $\begin{array}{c}\mathrm{SO}_{4} \\
(\mathrm{ppm})\end{array}$ \\
\hline 5702 & 1166 & 2.269 & 8.5 & 0 & 37.6 & 23.5 & 15.9 & & 114 & 24.5 & 43.7 \\
\hline 5703 & 1374 & 2.256 & 8.5 & 0 & & & & & 114 & 21.1 & 45.0 \\
\hline 5801 & 1829 & 2.274 & 8.5 & 0 & & & & & 113 & 20.6 & 44.5 \\
\hline 5802 & 2300 & 2.283 & 8.5 & 1 & 37.0 & 23.4 & 15.9 & & 115 & 23.1 & 44.0 \\
\hline 5901 & 2761 & 2.292 & 8.6 & 2 & & & & & 116 & 21.0 & 45.1 \\
\hline 5902 & 3206 & 2.291 & 8.6 & 3 & 34.3 & 23.3 & 15.9 & & 115 & 22.0 & 44.3 \\
\hline 6101 & 3673 & 2.295 & 8.6 & 5 & & & & & & & \\
\hline 6102 & 4079 & 2.296 & 8.7 & 7 & 34.9 & 23.5 & 16.0 & & 116 & 21.7 & 44.8 \\
\hline 6201 & 4562 & 2.179 & 8.6 & 9 & & & & & & & \\
\hline 6301 & 4858 & 2.302 & 8.6 & 11 & 34.9 & 23.7 & 16.0 & & 116 & 25.4 & 45.0 \\
\hline 6302 & 5049 & 2.307 & 8.6 & 13 & & & & & & & \\
\hline 6401 & 5526 & 2.304 & 8.6 & 15 & & & & & 116 & 25.3 & 44.6 \\
\hline 6402 & 5674 & 2.262 & & & & & & & & & \\
\hline 6404 & 5696 & 1.242 & & 17 & & & & & & & \\
\hline 6405 & 5759 & 1.209 & & 17 & & & & & & & \\
\hline 6406 & 6097 & 1.207 & & 19 & 33.0 & 23.5 & 15.9 & & 116 & 25.4 & 44.8 \\
\hline 6501 & 6374 & 1.207 & & 20 & & & & & & & \\
\hline 6502 & 6666 & 1.206 & & 23 & 32.4 & 23.4 & 15.9 & & 116 & 25.3 & 44.9 \\
\hline 6601 & 7065 & 1.205 & & 24 & & & & & & & \\
\hline 6701 & 7234 & 1.209 & & & & & & & & & \\
\hline 6801 & 7408 & 1.208 & & 32 & & & & & & & \\
\hline 6802 & 7705 & 1.206 & & 32 & & & & & & & \\
\hline 6901 & 7898 & 1.208 & & 32 & & & & & & & \\
\hline 6902 & 8209 & 1.206 & & 32 & & & & & & & \\
\hline 7001 & 8353 & 1.208 & & & & & & & & & \\
\hline
\end{tabular}


Appendix Table 8. Analytical data for $\mathrm{Cr}-7$ experiment.

\begin{tabular}{|c|c|c|c|c|c|c|c|c|c|c|c|}
\hline Sample & Bed vol. & $\begin{array}{c}\text { Rate } \\
\text { (g/min) }\end{array}$ & pH & $\begin{array}{c}\mathrm{Cr} \\
(\mathrm{ppb})\end{array}$ & $\begin{array}{c}\mathrm{Ca} \\
(\mathrm{ppm})\end{array}$ & $\begin{array}{c}\mathrm{Mg} \\
(\mathrm{ppm})\end{array}$ & $\begin{array}{c}\text { Si } \\
\text { (ppm) }\end{array}$ & $\begin{array}{c}\mathrm{CO}_{3} \\
(\mathrm{ppm})\end{array}$ & $\begin{array}{c}\mathrm{Cl} \\
(\mathrm{ppm})\end{array}$ & $\begin{array}{c}\mathrm{NO}_{3} \\
\text { (ppm) }\end{array}$ & $\begin{array}{c}\mathrm{SO}_{4} \\
\text { (ppm) }\end{array}$ \\
\hline 7501 & 0 & 0.000 & 8.6 & 2970 & 34.4 & 23.1 & 15.9 & 233.4 & 0 & 0.0 & 0 \\
\hline 7601 & 9 & 1.176 & 3.5 & 0 & 33.5 & 22.5 & 14.1 & 4.7 & 0 & 0.0 & 424 \\
\hline 7602 & 30 & 1.228 & 8.0 & 0 & & & & 126.7 & & & \\
\hline 7603 & 62 & 1.215 & 8.5 & 0 & 34.4 & 23.2 & 15.5 & & 19 & 0.0 & 216 \\
\hline 7604 & 93 & 1.218 & 8.5 & 0 & & & & 213.0 & & & \\
\hline 7605 & 124 & 1.218 & 8.6 & 0 & & & & & & & \\
\hline 7606 & 155 & 1.212 & 8.6 & 0 & 34.2 & 23.1 & 15.7 & 226.5 & 98 & 0.0 & 89 \\
\hline 7607 & 187 & 1.213 & 8.6 & 0 & & & & & & & \\
\hline 7608 & 218 & 1.210 & 8.6 & 0 & 34.4 & 23.1 & 15.8 & 234.5 & 106 & 0.0 & 72 \\
\hline 7609 & 249 & 1.217 & 8.6 & 0 & & & & & & & \\
\hline 7610 & 280 & 1.221 & 8.7 & & & & & & & & \\
\hline 7611 & 312 & 1.217 & 8.6 & 0 & $33.9^{\circ}$ & 23.0 & 15.6 & 231.6 & 107 & 3.9 & 63 \\
\hline 7612 & 343 & 1.212 & 8.6 & & & & & & & & \\
\hline 7701 & 375 & 1.252 & 8.7 & 0 & & & & & & & · \\
\hline 7702 & 407 & 1.254 & 8.7 & & & & & & & & \\
\hline 7703 & 439 & 1.244 & & 0 & & & & & & & \\
\hline 7704 & 471 & 1.237 & 8.7 & & 32.7 & 22.8 & 15.5 & & 105 & 17.3 & 51 \\
\hline 7705 & 503 & 1.225 & & 0 & & & & & & & \\
\hline 7706 & 534 & 1.217 & 8.7 & & & & & & & & \\
\hline 7707 & 565 & 1.213 & & 0 & & & & & & & \\
\hline 7708 & 596 & 1.213 & & & & & & & & & \\
\hline 7709 & 627 & 1.212 & 8.7 & 0 & 33.8 & 23.1 & 15.7 & & 107 & 22.9 & 48 \\
\hline 7710 & 659 & 1.213 & & & & & & & & . & \\
\hline 7711 & 690 & 1.201 & & 0 & & & & & & & \\
\hline 7712 & 720 & 1.201 & 8.7 & & & & & & & & \\
\hline
\end{tabular}


Appendix Table 8. (Continued)

\begin{tabular}{|c|c|c|c|c|c|c|c|c|c|c|c|}
\hline Sample & Bed vol. & $\begin{array}{c}\text { Rate } \\
(\mathrm{g} / \mathrm{min})\end{array}$ & pH & $\begin{array}{c}\mathrm{Cr} \\
(\mathrm{ppb})\end{array}$ & $\begin{array}{c}\mathrm{Ca} \\
(\mathrm{ppm})\end{array}$ & $\begin{array}{c}\mathbf{M g} \\
\text { (ppm) }\end{array}$ & $\begin{array}{c}\mathrm{Si} \\
\text { (ppm) }\end{array}$ & $\begin{array}{c}\mathrm{CO}_{3} \\
\text { (ppm) }\end{array}$ & $\begin{array}{c}\mathrm{Cl} \\
\text { (ppm) }\end{array}$ & $\begin{array}{c}\mathrm{NO}_{3} \\
(\mathrm{ppm})\end{array}$ & $\begin{array}{c}\mathrm{SO}_{4} \\
(\mathrm{ppm})\end{array}$ \\
\hline 7713 & 751 & 1.199 & & 0 & & & & & & & ? \\
\hline 7714 & 782 & 1.210 & 8.7 & & 33.1 & 22.8 & 15.7 & & 107 & 22.5 & 46 \\
\hline 7715 & 813 & 1.209 & & 0 & & & & & & & \\
\hline 7716 & 845 & 1.213 & & & & & & & & & \\
\hline 7717 & 876 & 1.212 & 8.7 & 2 & & & & & & & \\
\hline 7718 & 907 & 1.207 & & & & & & & & & \\
\hline 7719 & 938 & 1.220 & 8.7 & 2 & 32.8 & 23.0 & 15.7 & & 106 & 22.6 & 46 \\
\hline 7801 & 970 & 1.235 & & & & & & & & & \\
\hline 7802 & 1002 & 1.227 & 8.7 & 2 & & & & & & & \\
\hline 7803 & 1033 & 1.220 & & 3 & & & & & & & \\
\hline 7804 & 1064 & 1.216 & 8.7 & 3 & & & & & & & \\
\hline 7805 & 1095 & 1.213 & & 3 & & & & & & & \\
\hline 7806 & 1109 & 1.226 & 8.7 & 3 & & & & & & & \\
\hline
\end{tabular}

